\title{
EFFECTS OF FUNGICIDE AND ACETYLSALICYLIC ACID TREATMENTS ON THE PHYSIOLOGICAL AND ENZYMATIC ACTIVITY IN TOMATO (LYCOPERSICON ESCULENTUM MILL.)
}

- research paper -

\author{
Aurelia HOROTAN $^{* 1}$, Simona OANCEA ${ }^{* *}$ \\ *University of Agricultural Sciences and Veterinary Medicine, Cluj-Napoca \\ and Terezianum Technical College of Food Industry, Sibiu, Romania \\ ${ }^{* *}$ Lucian Blaga University of Sibiu, Department of Agricultural Sciences and \\ Food Engineering, Sibiu, Romania
}

\begin{abstract}
:
The paper deals with investigation of growth parameters of vegetative organs, peroxidase and catalase activities of Lycopersicon esculentum Mill. treated with a systemic fungicide and acetylsalicylic acid, respectively. Our results showed that both fungicide and acetylsalicylic acid lead to growth delays in tomato stems and leaves compared to control samples. During the growth, pathogen was rapidly inhibited by tomatoes treated with acetylsalicylic acid, affecting few plants (10\%) compared to control group (40\%). Results showed that samples treated with acetylsalicylic acid and control samples fructified better (30\% higher) than tomatoes treated with fungicide. The latter did not suffer pathogen attack, but catalase activity was increased (107 $\mathrm{mg} \mathrm{H}_{2} \mathrm{O}_{2} / 100 \mathrm{~g} \mathrm{FW}$ ) indicating oxidative stress. Activity of catalase and peroxidase in control and acetylsalicylic acid treated plants were of similar increased values, probably due to the pathogen infection. In particular, peroxidase activity increased during tomato fructification. Alternative substitution of fungicides with aspirin may improve tomato quality and production.
\end{abstract}

Key words: Lycopersicon esculentum, fungicides, acetylsalicylic acid, peroxidase, catalase

1 Corresponding author. 3-5 Calea Mănăştur Street, 400372, Cluj-Napoca and 18 Postăvarilor Street, 550340 Sibiu, Romania, E-mail: aurahorotan@yahoo.com, aureliahorotan.wordpress.com

Acta Universitatis Cibiniensis Series E: FOOD TECHNOLOGY 


\section{INTRODUCTION}

Vegetables are plant foods known for their nutritional value and therapeutic effects. Vegetable consumption stimulates body hydration, muscle activity, appetite, calcification, enzyme activity, defense ability, inhibits bacterial fermentation, and supplies essential amino acids (Suciu et al., 1987).

Whole benefits of fresh fruits and vegetables are to be obtained by organic grown ones. It is known that by consumption of non-organic plant foods, traces of insecticides, fungicides or herbicides are most likely to remain in plant, in particular in peels and leaves.

Plants are particularly influenced by environmental stress. Abiotic constraints are responsible for oxidative stress, which causes imbalances between prooxidants and antioxidants. In fact, the common denominator of these adverse conditions is overproduction of reactive oxygen species (ROS) in different cellular compartments of plant tissues. Formation of ROS is initiated by reduction of molecular oxygen using electrons, to generate superoxide $\left(\mathrm{O}_{2}{ }^{-}\right)$, hydrogen peroxide $\left(\mathrm{H}_{2} \mathrm{O}_{2}\right)$ and hydroxyl radical $\left(\mathrm{OH}^{*}\right)$ (Cheruth et al., 2009). The accumulation of high concentrations of ROS has a high potential of toxicity to plant cells as it produces damage to valuable compounds (DNA, proteins, lipids) or to cellular components (chloroplast, membranes). It is known that plants resist ROS-induced stress by increasing the natural components of their defense system, a complex of non-enzymatic and enzymatic antioxidants, such as superoxide dismutase (SOD), ascorbate peroxidase (APX), catalase (CAT), peroxidase (POX). The enzymes peroxidase and catalase, play an essential role in the processes of purification, in particular in conjunction with SOD (Cheruth et al., 2009). These enzymes were studied in different plant species, especially in horseradish (Armoracia rusticana), under the influence of stress factors such as temperature, $\mathrm{pH}$, and various compounds as minerals or salicylic acid (Larkindale et al., 2005).

Regarding tomato plant, latest studies focused on carotene/lycopene activity, as these compounds are related to the therapeutic effects on human health.

In the present paper, we investigated the growth of vegetative organs and monitored the enzymatic (peroxidase and catalase) activity in a comparative study regarding the influence of selected systemic fungicides and acetylsalicylic acid in tomato (Lycopersicon esculentum Mill.). We have selected these two types of growth promoters because fungicides, regardless of their origin (manufacturer), concentration or use, are toxic to both 
environment and human health, causing lot of discussion and global controversy.

\section{MATERIALS AND METHODS}

\section{Plant material and growth}

Tomato (Lycopersicon esculentum Mill.) Heinz 2274 variety was selected and grown for physiological parameters study (Zamfir, 1993). This variety is semi-early and resistant to fungi of Phylum Ascomycota, such as Verticillium and Fusarium.

Solanum lycopersicum L. (Lycopersicon esculentum Mill.) is a herbaceous plant, vegetable, with therapeutic value. Tomatoes have a differentiated tissues structure with different chemical composition and physiological activity. For this study, we have used the tomato leaves and stems harvested from each experimental group.

A number of 150 hydrated seeds were sown on 3 experimental groups: (1) control group (LM), (2) fungicide group (LF), and (3) acetylsalicylic acid group (LA). Plants remained for 86 days in trays, after which were planted in field. Time measurements were made to trace the growth parameter of vegetative organs, stem and leaf. There have been done 6 measurements at different time intervals. The first measurement was made at 29 days after sowing, when the number of plants sprung remains relatively constant as shown in Table 1.

Table 1. Graphic measurements during tomatoes growth

\begin{tabular}{|c|c|c|c|}
\hline $\begin{array}{c}\text { Measurement } \\
\text { no. }\end{array}$ & Period & $\begin{array}{c}\text { Number of days } \\
\text { after sowing }\end{array}$ & $\begin{array}{c}\text { Total no. of } \\
\text { investigated plants }\end{array}$ \\
\hline T1 & 27.02 .2012 & 29 & 125 \\
\hline T2 & 04.03 .2012 & 35 & 124 \\
\hline T3 & 11.03 .2012 & 42 & 115 \\
\hline T4 & 18.03 .2012 & 49 & 115 \\
\hline T5 & 10.04 .2012 & 72 & 115 \\
\hline T6 & 09.06 .2012 & 132 & 115 \\
\hline
\end{tabular}

Photoperiod (www.astro-urseanu.ro) was calculated for all the growth period from emergence to harvest as presented in Figure 1. Tomatoes have benefited from the maximum daylight hours, without being influenced the photosynthesis process.

Acta Universitatis Cibiniensis Series E: FOOD TECHNOLOGY 


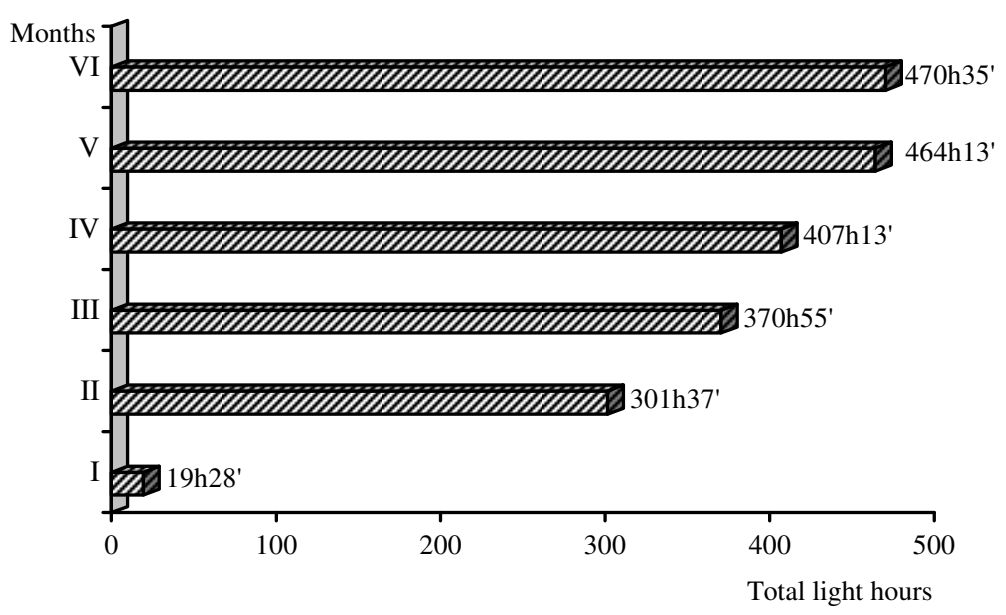

Figure 1. Tomatoes photoperiod for the time interval of 30.01.2012 - 30.06.2012

Each group was watered daily with tap water, 150 to $200 \mathrm{ml}$ to emergence. After seedlings emergence, the irrigation water volume was increased to 400 $\mathrm{ml}$, and after being planted in the experimental zone (boxes made of wood lined with plastic - Figure 2), progressively increased up to 8 liters of water/group.

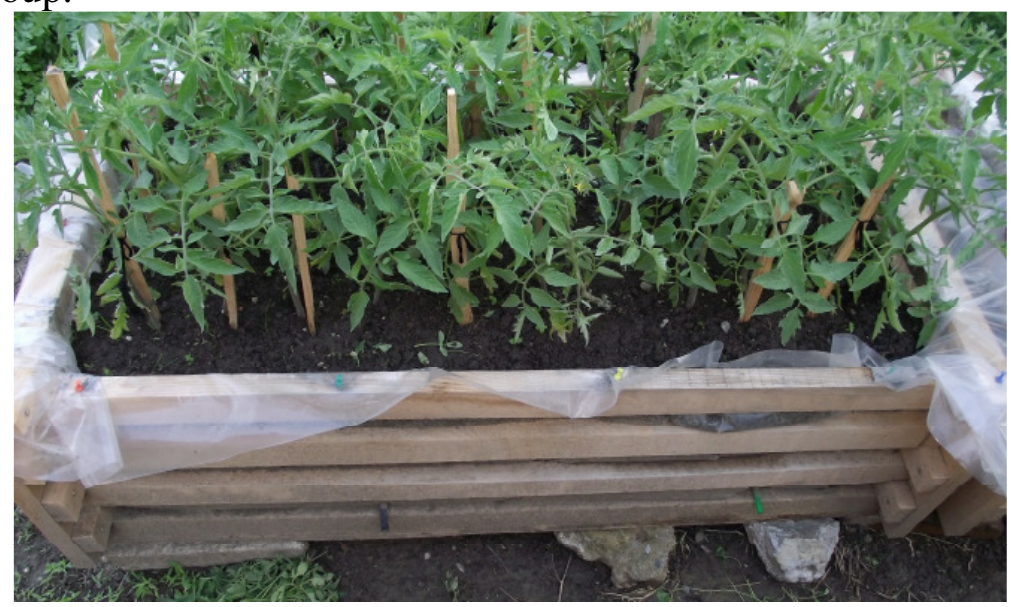

Figure 2. Experimental LA groups planted in wooden boxes lined with plastic.

Growth temperature of tomatoes in trays was maintained at values between $17-19^{\circ} \mathrm{C}$. After field plantation, the air temperature averages have ranged Vol. XVII (2013), no.1 
between $11-20^{0} \mathrm{C}$ (Figure 3). Monthly average temperatures was provided by Transylvania South Sibiu Regional Meteorological Center.

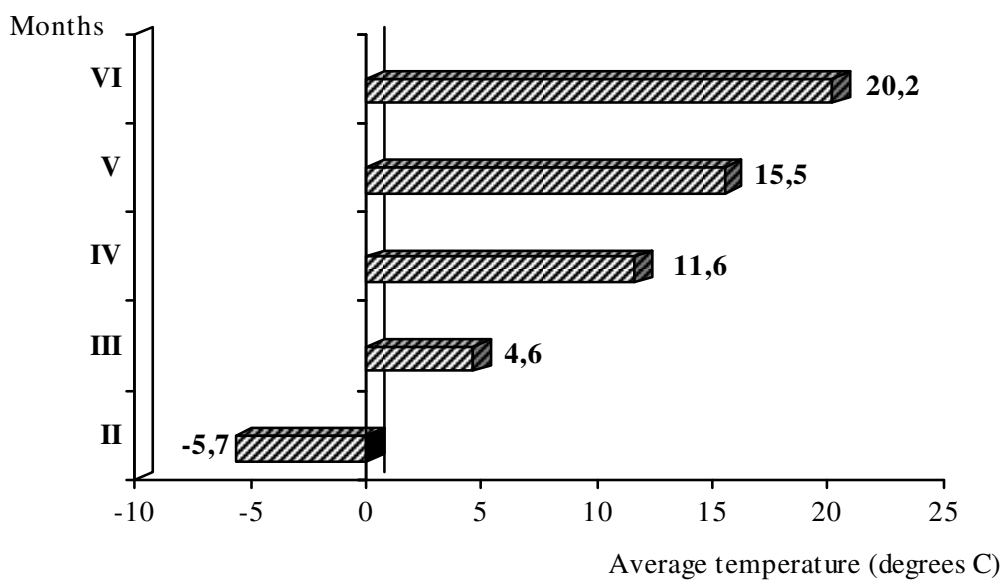

Figure 3. Monthly average temperature $\left({ }^{0} \mathrm{C}\right)$ for the time interval of 01.02.2012 - 20.06.2012

\section{Tomato plants treatments}

Tomatoes were sprinkled with 3 different types of treatment: (1) Acrobat MY 90/600 (WP, bag of $20 \mathrm{~g}$ ), a systemic fungicide with moderate toxicity, (2) acetylsalicylic acid $(500 \mathrm{mg})$, and (3) tap water. Sprinkling tomatoes with experimental solutions was performed in the LF with $2 \%$ systemic fungicide (20 g/10 1 water $/ 100 \mathrm{~m}^{2}$ ), in the LA group with $0.5 \%$ acetylsalicylic acid solution $\left(5 \mathrm{~g} / 101\right.$ water/100 $\left.\mathrm{m}^{2}\right)$ and in $\mathrm{LM}$ with tap water $10 \mathrm{l} / 100 \mathrm{~m}^{2}$. Between 06.03.2012 - 20.06.2012 9 splashes prepared before each spraying solutions were made, at 10-14 days.

Biochemical analyses regarding enzymatic activity were performed by a graph analysis, according to the schedule of spraying tomatoes (Table 2), on fresh tomato leaves.

Peroxidase and catalase extraction and assay

Peroxidase extraction was performed on $10 \mathrm{~g}$ of fresh tomato leaves from each experimental group, and $2 \% \mathrm{NaCl}$. Determination of peroxidase activity was done by spectrophotometric method, using the chromogenic substrate of $p$-phenylenediamine (Luck, 1963). The Cecil CE1021 spectrophotometer was used.

Peroxidase activity was noted as following: POXM for control group, POXA for acetylsalicylic acid group and POXF for fungicide group. 
Catalase extraction was performed using $2 \mathrm{~g}$ of fresh tomato leaves from each experimental group, and phosphate buffer $\mathrm{pH}$ 6.8. The activity of catalase was assayed after the method of Chance, Maehly (Chance et al., 1955). Enzyme activity was expressed as $\mathrm{mg} \mathrm{H}_{2} \mathrm{O}_{2} / 100 \mathrm{~g}$ fresh weight.

Catalase activity was noted as following: CATM for control group, CATA for acetylsalicylic acid group and CATF for fungicide group.

\section{RESULTS}

The average growth parameters for the experimental groups in the interval 27.02.2012-09.06.2012 are presented in Figure 4.

By early March there were no significant differences between seedlings, following a short period when fungicide treated plants showed tendency to grow faster than the plants in the control groups and acetylsalicylic acid treated plants. With the beginning of April (T5 - 10.04.2012) LM stems are growing strong, being thus delimited from the other experimental groups.

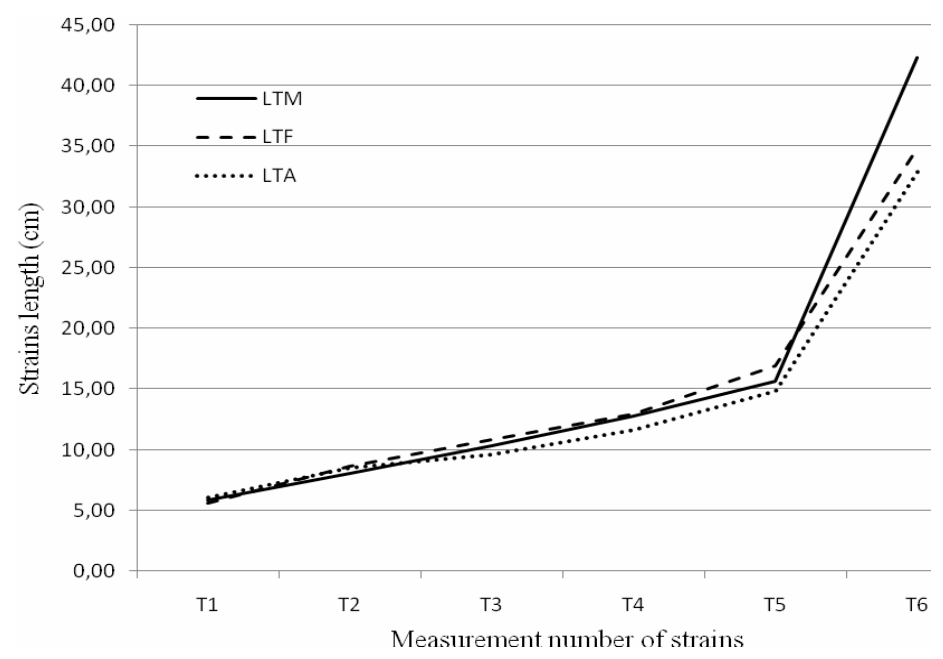

Figure 4. Variation of average growth of strains to experimental groups of Lycopersicon esculentum (for 15 weeks)

In comparison to stem length measurements, the length of tomato leaves was measured for all experimental groups (fungicide, acetylsalicylic acid and control group). The calculated average values are presented in Figure 5. Leaf growth showed differences from the seedling stage. At the interval of 35 days after sowing (T2), a slower growth in LA was observed, while the other two 
groups presented a relatively steady growth. Early April (T5) marked an accelerated growth of tomato foliar in the acetylsalicylic acid treated group, with a tendency to overcome the group sprayed with fungicide.

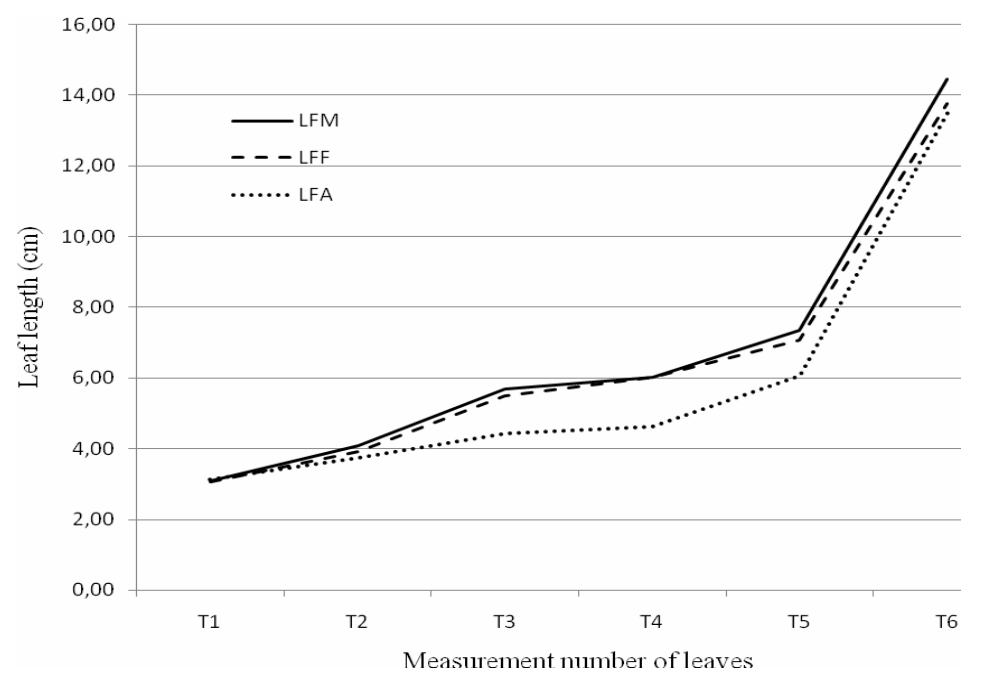

Figure 5. Variation of average growth of leaves to experimental groups of Lycopersicon esculentum (for 15 weeks)

Catalase activity (CAT) was determined by $\mathrm{H}_{2} \mathrm{O}_{2}$ consumption calculated in $\mathrm{mg} / 100 \mathrm{~g}$ fresh weight, for a period of 15 weeks. The obtained results are shown in Figure 6. In the fungicide group, the amount of $\mathrm{H}_{2} \mathrm{O}_{2}$ calculated per $100 \mathrm{~g}$ FW exceeds $100 \mathrm{mg}$, while in the control group, slowly exceeds 80 $\mathrm{mg} / \mathrm{FW}$, in early March. After a week (analysis 2 in Figure 6), the enzymatic activity was increased in the acetylsalicylic acid group of plants, which recorded a significant increase (107 $\left.\mathrm{mg} \mathrm{H}_{2} \mathrm{O}_{2} / 100 \mathrm{~g} \mathrm{FW}\right)$. In late April (analysis 5 in Figure 6) the pathogen attack was observed in several tomato plants in LM. Although the attack extends to the group sprayed with acetylsalicylic acid, catalase activity is decreased in all experimental groups. In the group sprayed with fungicide, there was no pathogen attack and catalase activity steadily decreases reaching values below those recorded in other experimental groups. Another element that coincides with decreased enzyme activity is the flourishing tomatoes, a process that begins in April, graph period between 5 and 6 . After flowering, there followed a brief period of very low intensity activity. 
Peroxidase activity showed significant increase since the early stages of tomato growth, in particular in the group treated with fungicide (POXF), compared to those of the group treated with acetylsalicylic acid (POXA), as seen in Figure 7. Peroxidase activity increased showing high values in early May (analysis 6 in Figure 7), when pathogen attack has expanded to the LM and affected LA, too. Thus, to the $6^{\text {th }}$ analysis, POXM values reached 18.22 EU/g FW, POXF at 15.74 EU/g FW and POXA at $15.58 \mathrm{EU} / \mathrm{g} \mathrm{FW.}$

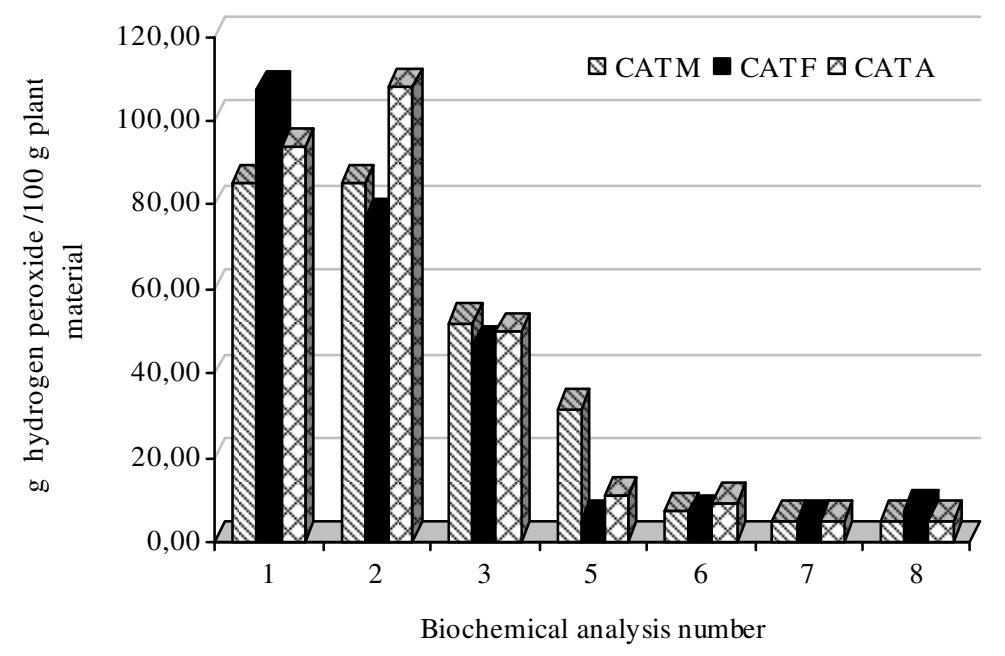

Figure 6. Catalase activity in the samples of experimental groups of Lycopersicon esculentum, for a period of 15 weeks

\section{DISCUSSION}

Differences in growth was observed in April, when control group recorded values exceeding those of plants treated with fungicide and acetylsalicylic acid. Among the latter there was no difference, their stems following a relatively steady growth curve. Regarding the influence of the investigated fungicide and acetylsalicylic acid treatments, the systemic fungicide containing a mixture of dimetomorf and mancozeb, and the acetylsalicylic acid caused slight delays in stem growth. Similar effects were not confirmed for the leaves experimental groups. Unlike stem growth, LF leaf growth values were found decreased but relatively close to those of LM.

However, after mid-April and almost all May, the weather conditions were not favourable, being characterized by rains over 10-15 1 water $/ \mathrm{m}^{2}$ (Figure 8). Relative humidity was close to the value of $100 \%$, which did not allow 
application of different treatments to plants. These conditions determined a LM advanced growth.

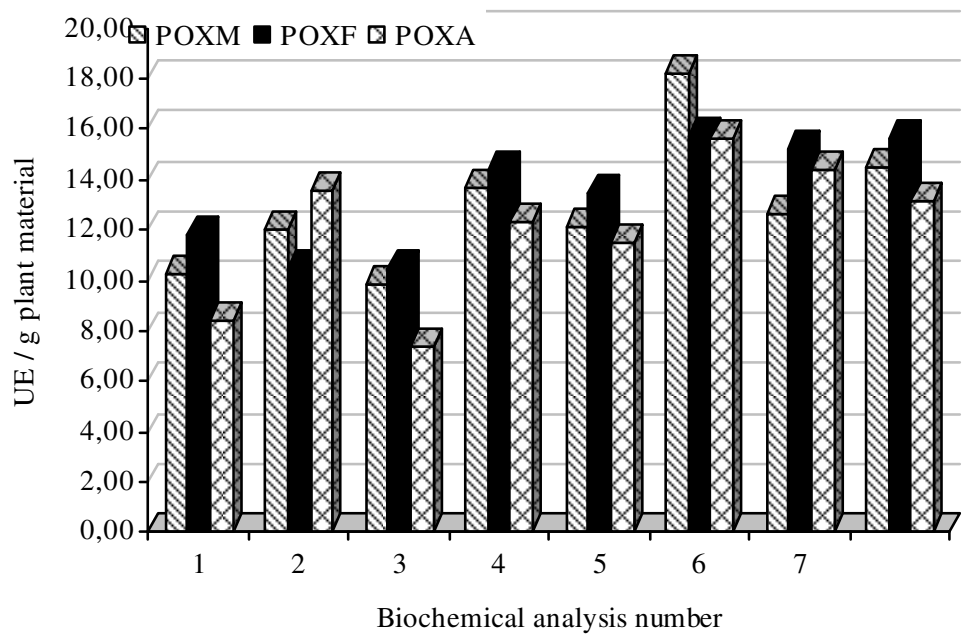

Figure 7. Peroxidase activity in the samples of the experimental groups of Lycopersicon esculentum, for a period of 15 weeks

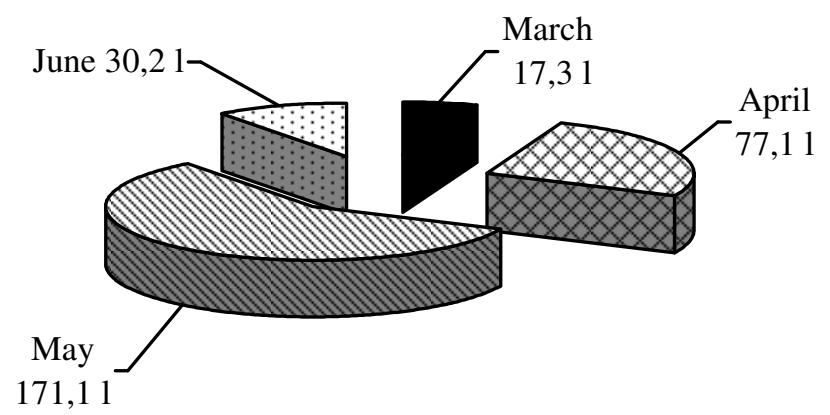

Figure 8. Monthly amount of precipitation for the interval February to June 2012

Tomato growth of LM was not affected by pathogen attack, which was first seen in late April. In about three weeks, pathogen attack was inhibited by the natural defense system of tomatoes, which have continued to grow. 
Physiologically, tomatoes growth was influenced by fungicide and acetylsalicylic acid applied solutions. The apllied treatments influenced also flowering and fructification, phenomena followed by late June. First flowers appeared in the group treated with fungicide (LF), followed by acetylsalicylic acid group (LA) and control group (LM) (Figure 9). Fungicide accelerates tomatoes flowering, which confirms preliminary studies (unpublished) underlying this work, but inhibate the fructification.

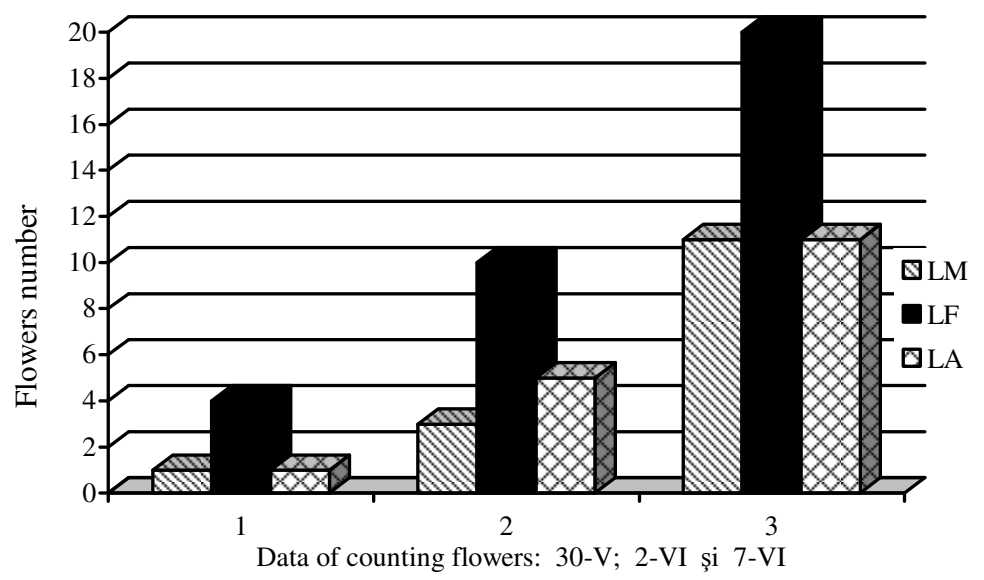

Figure 9. Tomato flowering parameters from the studied experimental groups

Tomatoes from the three experimental groups were similarly treated (soil watering, weeding, and digging). It was observed that tomatoes treated with acetylsalicylic acid and those used as control formed beautiful, moist and fragrant fruits. LF tomatoes showed dried leaves, lighter, with a smell of a mixture of tomatoes - chemicals stifling.

Mechanism of plant metabolism responds differently to their exposure to different stress factors, which is essential in determining the ability of plants to survive. However, genetic factors determine whether the plant is able to survive and continue to reproduce.

Plants posses natural defense systems against pathogens. In response to pathogen attack, plants triggers defense mechanisms, including accelerating the production and accumulation of ROS. ROS generates superoxide, hydrogen peroxide and hydroxyl radical, known like toxic metabolites to cells (Cavalcanti et al., 2006). An overproduction of $\mathrm{H}_{2} \mathrm{O}_{2}$ may cause severe cell damage and metabolism imbalances. This compound, however is destructive for pathogens. Some authors have shown that plants attacked by 
pathogens are capable of producing ROS in an amount sufficient to inhibit pathogen infection as well as to control the enzyme response (Patykowski et al., 2006).

The enzyme catalase is present in aerobic cells peroxisome and absent in chloroplasts. It protects cells by catalyzing decomposition of hydrogen peroxide. Some studies on catalase activity in the horticultural crops, showed specific late response of this enzyme in case of induced infection with different pathogens (Cavalcanti et al., 2006).

In our study, the early period of plant vegetation induced an increase in catalase activity in CATF group, marking the produced oxidative stress. Thus, the plant has triggered a defense mechanism leading to the formation of $\mathrm{H}_{2} \mathrm{O}_{2}$. In the CATF group the activity of catalase was increased when tomatoes were in the seedling stage. After this period, the enzymatic activity decreased progressively with the growth of vegetative organs. At the end of March (analysis 3), catalase activity values were not significant in the group treated with fungicide, probably because the fungicide acted as a catalase inhibitor. This phenomenon is in agreement with the research studies which have shown that systemic fungicides decrease the $\mathrm{H}_{2} \mathrm{O}_{2}$ production (Garcia et al., 2003), so that the plants are unable to defend themselves.

Regarding the control groups (CATM) and acetylsalicylic acid treated group (CATA), the catalase activity remained increased until the beginning of May, a period that includes the pathogen presence. Activity of this enzyme is maintained during the pathogen attack, registered at the end of April, first in the control group (CATM) and then in acetylsalicylic acid group (CATA). Thus, when the plant was attacked by the pathogen, the defense mechanism was triggered producing a large amount of ROS. Our results have shown that acetylsalicylic acid does not produce oxidative stress. Amount of $\mathrm{H}_{2} \mathrm{O}_{2}$ converted in the presence of catalase in control group was relatively close to that of the group treated with acetylsalicylic acid (LA).

The peroxidase activity measured in the three experimental groups, was found higher in tomatoes fungicide group (POXF), indicating the installed oxidative stress. Tomatoes treated with acetylsalicylic acid (POXA) behavioured relatively equal regarding the peroxidase activity in the LM group. As obtained in case of catalase activity, acetylsalicylic acid did not induce oxidative stress in the studied plants. Instead, the pathogen causes obvious changes in enzyme activity from LA group. Peroxidase activity reached the highest values in the $6^{\text {th }}$ analysis for all the experimental groups. These values are due to the tomato fructification (fallen petals, well developed ovary) confirming other reported studies. Cheruth et al (2009) 
have shown that peroxidases are involved in auxins catabolism, these hormones activity being increased during maturation and fruit ripening. Some studies have shown that peroxidase activity and its various isoformes increases at the end of the plant growth, during the formation and maturation of fruits (Savic et al., 2008). Savic et al (2008) measured cell wall peroxidase activity at 15 days after tomatoes fructification, because by this time the results showed no differences of peroxidase activity between the investigated treatments (irrigation treatments based methods). Peroxidase is part of the plant defense system, which proved to be effective for the studied tomato groups in our investigation. This is confirmed by studies reported by Garcia et al (2003) in tobacco leaves which were sprayed with a systemic fungicide containing carbendazim, at $1.3 \mathrm{mM}, 2.6 \mathrm{mM}$, and $5.2 \mathrm{mM}$, respectively.

The obtained results on the studied oxidative enzymes activity cannot be limited to the investigated stressors, fungicide and acetylsalicylic acid, because other factors such as stress produced by the pathogen may interfere.

The present study was performed on tomatoes originating from natural living environment (garden), not from a laboratory model. We followed their evolution under natural conditions, so that the study may find application in small gardens set without marketing purposes, by avoiding the use of harmful fungicides.

\section{CONCLUSIONS}

The study regarding the influence of fungicide and acetylsalicylic treatments on Lycopersicon esculentum Mill. was conducted at two levels, physiological and biochemical. The planted tomato seeds were divided into the two treated groups and a control group. At the end of the experiment, from the physiological point of view, the following may be concluded:

- fungicide and acetylsalicylic acid lead to growth delays in tomato stems;

- acetylsalicylic acid solution have also caused the delay of leaves growth;

- fungicide solution did not affect the leaf growth;

- high relative humidity favoured the growth of control group and acetylsalicylic acid group tomatoes, starting from April, because acetylsalicylic acid solution was diluted;

- growth of control group and acetylsalicylic acid group tomatoes was not inhibited by pathogen attack occurred in late April.

- tomato flowering was accelerated by systemic fungicide solution;

Acta Universitatis Cibiniensis Series E: FOOD TECHNOLOGY 
- control group and acetylsalicylic acid group tomatoes fructify $30 \%$ more than fungicide group tomatoes. Probably the fungicide solution inhibited the insect pollinated activity;

- fungicides influenced the structure of mechanical tissues and fruits skin which became breakable;

Regarding the biochemical studies, two oxidative enzyme activities - catalase and peroxidase from vegetative organs of the species Lycopersicon esculentum Mill. were studied. The following can be concluded:

- fungicide produced oxidative stress on tomato seedlings and planting;

- in mature plants, fungicide solution inhibited the catalase activity;

- the control group and acetylsalicylic acid group tomatoes showed high catalase and peroxidase activity due to the pathogen infection, these enzymes being actively involved in the defense system of the plant;

- acetylsalicylic acid solution did not induce oxidative stress in mature tomato plants;

- peroxidase activity increased during fructification of selected tomatoes.

\section{LIST OF ABBREVATIONS}

\begin{tabular}{|l|l|}
\hline CAT & = Catalase \\
CATA & = Catalase activity of tomatoes from acetylsalicylic acid group \\
CATF & = Catalase activity of tomatoes from fungicide group \\
CATM & = Catalase activity of tomatoes from control group \\
FW & = Fresh weight \\
LA & = Acetylsalicylic acid group \\
LF & = Fungicide group \\
LM & = Control group \\
LFA & = Leaves lenght of acetylsalicylic acid group \\
LFF & = Leaves lenght of fungicide group \\
LFM & = Leaves lenght of control group \\
LTA & = Stem lenght of acetylsalicylic acid group \\
LTF & $=$ Stem lenght of fungicide group \\
LTM & $=$ Stem lenght of control group \\
POX & $=$ Peroxidasa \\
POXA & $=$ Peroxidase activity of tomatoes from acetylsalicylic acid group \\
POXF & $=$ Peroxidase activity of tomatoes from fungicide group \\
POXM & $=$ Peroxidase activity of tomatoes from control group \\
ROS & $=$ Reactive oxygen species $\left(\mathrm{O}_{2}^{+}, \mathrm{H}_{2} \mathrm{O}_{2}\right.$, OH) \\
Tn & Number of measurements \\
(n=1 ... 6) &
\end{tabular}

Acta Universitatis Cibiniensis Series E: FOOD TECHNOLOGY

Vol. XVII (2013), no.1 


\section{REFERENCES}

1. Cavalcanti F. R., Vilela-Resende M. L., Lima J. P., Silveirac J. A., Oliveira J. T., Activities of antioxidant enzymes and photosynthetic responses in tomato pre-treated by plant activators and inoculated by Xanthomonas vesicatoria, Physiological and Molecular Plant Pathology, 2006, 68, 198-208

2. Chance B., Maehly A. C., Assay of catalase and peroxidases. Methods Enzymol, 1955, 2, 764-775

3. Cheruth A. J., Ksouri R., Ragupathi G., Paramasivam M., Jallali I., Hameed J., Zhao C. X., Shao H. B., Rajaram P., Antioxidant defense reponses: physiological plasticity in higher plants under abiotic constraints, Acta Physiol Plant, 2009, 31, 427 - 436

4. Garcia P. C., Rivero R. M., Ruiz J. M., Romero L., The Role of Fungicides in the Physiology of Higher Plants: Implications for Defense Responses, The Botanical Review, 2003, 69 (2), 162-172

5. Larkindale J., Bingru H., Effect of abscisic acid, salicilic acid, ethylene and hydrogen peroxid in thermotolerance and recovery for creeping bentgrass, Plant Growth Regulation, 2005, 47, 17 - 28

6. Luck H., Peroxidase. In Methods of Enzymatic Analysis edited by Bergmeyer H.U., Academic Press, New York, 1963, 895-897

7. Patykowski J., Role of hydrogen peroxide and apoplastic peroxidase in tomato - Botrytis cinerea interaction, Acta Physiologiae Plantarum, 2006, 28(6), 589-598

8. Oancea S., Toxicologie alimentară şi elemente de toxicologia mediului, edited by Oancea S., Ed. Universităţii "Lucian Blaga" din Sibiu, Sibiu, 2006

9. Savic S., Stikic R., Vucelic-Radovic B., Bogicevic B., Jovanovic Z., Hadz-Taskovic Sukalovic V., Comparative effects of regulated deficit irrigation (RDI) and partial root-zone drying (PRD) on growth and cell wall peroxidase activity in tomato fruits, Scientia Horticulturae, 2008, $117,15-20$

10. Suciu Z., Pleşca T., Goian M., Cultura legumelor în grădină, seră şi solar, edited by Suciu Z., Pleşca T., Goian M., Ed. Facla, Timişoara, 1987

11. Zamfir A., Ecofiziologia plantelor : Indrumător de lucrări practice, edited by Zamfir A., ULB Sibiu, 1993

12. $* * *$ www.astro-urseanu.ro/rasarit_soare_blank.html 